\title{
Regionalization of Production and Foreign Trade of Vegetables in the European Union
}

\author{
Agnieszka TARNOWSKA ${ }^{1}$, Ivan SOUKAL $^{2}$ \\ ${ }^{1}$ Wroclaw University of Economics, Wroclaw, Poland \\ agnieszka.tarnowska@ue.wroc.pl \\ ${ }^{2}$ University of Hradec Králové, Hradec Králové, Czech Republic \\ ivan.soukal@uhk.cz
}

\begin{abstract}
Vegetables are a very important and valuable ingredient in a healthy and varied diet. According to FAO/WHO experts recommendation a day should be consumed about 400 grams of vegetables and fruits. Current production in the world as well as in the EU is insufficient to cover the recommended intake. Vegetable production in the EU since 1962 was subject to regulations aimed at protecting the home market as well as selected producers. Since 2008, producers in the Community market have been subject to the same rules. This makes the EU vegetable market more competitive. However, the volume of their production varies regionally due to land resources, climate and technological advances. The largest producers of qualitative vegetables are the southern countries (Spain and Italy). Poland produces the most cabbages and carrots. Spain is Europe's largest net exporter of vegetables and this trade direction is of great economic importance for this country. The largest net importer of vegetables in the EU is Germany, which is not able to meet domestic demand.
\end{abstract}

Keywords: Vegetable Production, Internal EU Trade, External EU Trade.

\section{Introduction}

The term vegetable refers to the edible parts of plants. Welbaum [14] claims that vegetables are green plants or parts of plants that are eaten raw or cooked. In general, they are served as an entree or used to prepare salads and are not eaten for dessert. They require intensive care in cultivation and special care after harvest to preserve their quality.

At the FAO/WHO workshop promoting adequate consumption, the recommendations of experts on diet, nutrition and prevention of chronic diseases were reviewed. According to them, a day should be consumed about 400 grams of vegetables and fruits in five portions. However, it was found that the availability of these products increased only slightly in most countries. It is still at a level lower than the recommended intake in both developed and developing countries [8].

According to Eurostat figures, even in the European Union, 5 or more servings of vegetables and fruits a day consumed only $14.3 \%$ of its population and $34.4 \%$ did not 
eat them at all. More than half of the respondents in Bulgaria and Romania did not consume any fruit and vegetables [5]. In the light of these reports and recommendations, in times of greater care for health and fitness, the production and consumption of vegetables will increase. It is a market that is still growing and will continue to grow.

It is known that the best are fresh vegetables, seasonal, coming from the nearest surroundings. Are there opportunities in Europe to produce enough vegetables to meet the demand of EU citizens? Which countries are the biggest producers and exporters? Is there regional specialization in Europe? This article is mainly to give answers to these questions.

\section{Purpose, scope and methodology of research}

The aim of the article was a regional analysis of the vegetable market in the European Union. It focused on the production capacities of individual states and on import and export within the EU and with third countries. Total trade value analysis was accompanied by a question relative focus of surveyed countries.

The spatial scope of study covered all 28 EU states. Due to the completeness of the data and fluctuations in the economic situation, the three-year means were calculated for period 2014-2016.

The legal conditions governing the Community vegetable market were examined. Subsequently, the area of vegetable cultivation and their total production were analyzed. Further analysis was aimed at defining the structure of vegetable production in the EU. This made it possible to select six vegetables produced in the highest quantities in their most important groups. The selected six vegetables were: tomatoes, onions, carrots, cabbage, peppers and lettuce. Then, by examining the geographical structure of the production of the above-mentioned vegetables, ten of the largest producers were identified. In this part of the study, structure indicators and descriptive methods were used. The presentation of results was enriched with tables and graphs.

The hierarchical cluster analysis was used for further analysis of the total trade value and relative focus of each country. This procedure attempts to identify relatively homogeneous groups of cases based on selected variables, using an algorithm that starts with each case in a separate cluster and combines clusters until only one is left. For method description, metrics and segmentation criterion see e.g. [9, 11, 12, 13]. We used Squared Euclidean distance which is a suitable metrics for most recommended clustering algorithms such as Ward's and Centroid based. The latter one was employed. It is based on the geometric center of each cluster which is computed first. The distance between the two clusters equals the distance between the two centroids. Clusters are merged accordingly its distance. This method was chosen prior to the Ward's one since Ward's criterion tends to create outliers more frequently that cluster based criterion [12]. With a chosen metrics let us have linkage criterion for given $X_{1} \ldots X_{n}$ vectors and pairwise dissimilarities $d_{i j}=\left\|X_{i}-X_{j n}\right\|_{2}$. Let $\overline{X_{A}}, \overline{X_{B}}$ denote group averages for $A$ and $B$ groups. Then dissimilarity of groups is $d(A, B)=$ $\left\|\overline{X_{A}}-\overline{X_{B}}\right\|_{2}$. 
To validate the clustering solution we followed expert and agglomeration schedule point of view. Agglomeration schedule provides information on the objects being combined at each stage of the clustering process. We followed the "elbow rule" [11] which generally indicate the solution regarding where an additional combination of two objects or clusters would occur at a greatly increased distance. Thus, the number of clusters prior to this merger is the most probable solution.

For the second case of relative importance a standardization by case was performed (also known as ipsative standardization) in the data preparation phase. This method is employed in order to assess the difference in the survey sample concerning the scale [15]. The surveyed sample showed significant heterogeneity that comes mostly from the market size. Since the scale and units were the same for all employed variables smaller countries would be naturally discriminated in any distance metrics. Moreover, the most recommended metric of Square Euclidian distance even increases already present distance difference among the members. Therefore, a Z-scoring $[10$, 12] was applied as standardization by case.

\section{Legal regulations on the market of vegetables and fruits in the $\mathbf{E U}$}

The European Union, which wanted to protect the native market and very fragmented producers, introduced two systems regulating the turnover of vegetables and fruits. The first regulations appeared in 1962 and concerned fresh products. In 1978 there was introduced legislation on trade in the processed goods. Both market regulation systems assumed primarily of uniform quality standards, intervention mechanisms to maintain producer prices and incomes, and the application of a common customs tariff to protect the internal market from imports from third countries.

Pursuant to Council Regulation (EC) No 2200/96 of 28 October 1996 [1], the market for fresh vegetables and fruits was reformed. The aim was to link the production and trade of fresh fruits and vegetables to the environment. In addition, efforts were made to strengthen the position of producers and promote producer organizations.

Another Council Regulation (EC) No 2201/96 of 28 October 1996 [2] also introduced new rules for the organization of the common market in fruit and vegetable products. There are various forms of support. Asparagus producers were able to count on area subsidies in the 1997-1999 period. Tomato producers received subsidies if they directed their products for processing. Financial support was received by farmers through processing plants and producer groups.

Since January 1, 2008, the European Commission has introduced new regulations on the fruit and vegetable market [3]. The reform was intended to encourage manufacturers to join organizations and larger groups. This would result in the supply to the market of larger batches of raw material with a more evenly assortment. Another argument was the threat of growing competition from Asia and America. An important reason was the desire to further improve the environment. The budget for this operational program has been increased. 
The payment mechanism concerned the so-called decoupling, i.e. the change of payments for production to area payments. Processing payments have been abolished, but a four-year transitional period has been maintained for tomatoes to be sent to the processing plant. However, there was introduced the principle of payment for hectares of crops, rather than 1 ton of processed products. This has led to the unification of the conditions of fruit and vegetable producers in all the countries of the Community [7].

\section{$4 \quad$ Area and production volume of vegetables in the $\mathbf{E U}$}

Vegetable production in the world is growing. In 1980, there were produced $321 \mathrm{mln}$ tonnes, in $1990-466 \mathrm{mln}$ tonnes and in $2000-778 \mathrm{mln}$ tonnes. The latest figures from 2014 report $1169 \mathrm{mln}$ tonnes. There are also more and more people in the world, however, it is still recorded an increase in production per person. In 1980 one person in the world accounted for $7.3 \mathrm{~kg}$ of vegetables produced, in $1990-8.9 \mathrm{~kg}$, in $2000-$ $12.9 \mathrm{~kg}$. In 2014, when the world population was $7298 \mathrm{mln}$, per capita of the world was produced $16.0 \mathrm{~kg}$ of vegetables [6].

According to FAOSTAT in 2014 the total volume of vegetable production in the EU amounted to $67.7 \mathrm{mln}$ tonnes, representing $5.8 \%$ of world production of these crops. Their cultivation in the EU stretched on the surface of $2.3 \mathrm{mln}$ ha, i.e. $3.8 \%$ of the global acreage of these crops. The share of the vegetable area in the total utilized agricultural area is relatively small. In the world in 2014 it was only $1.25 \%$, in the EU

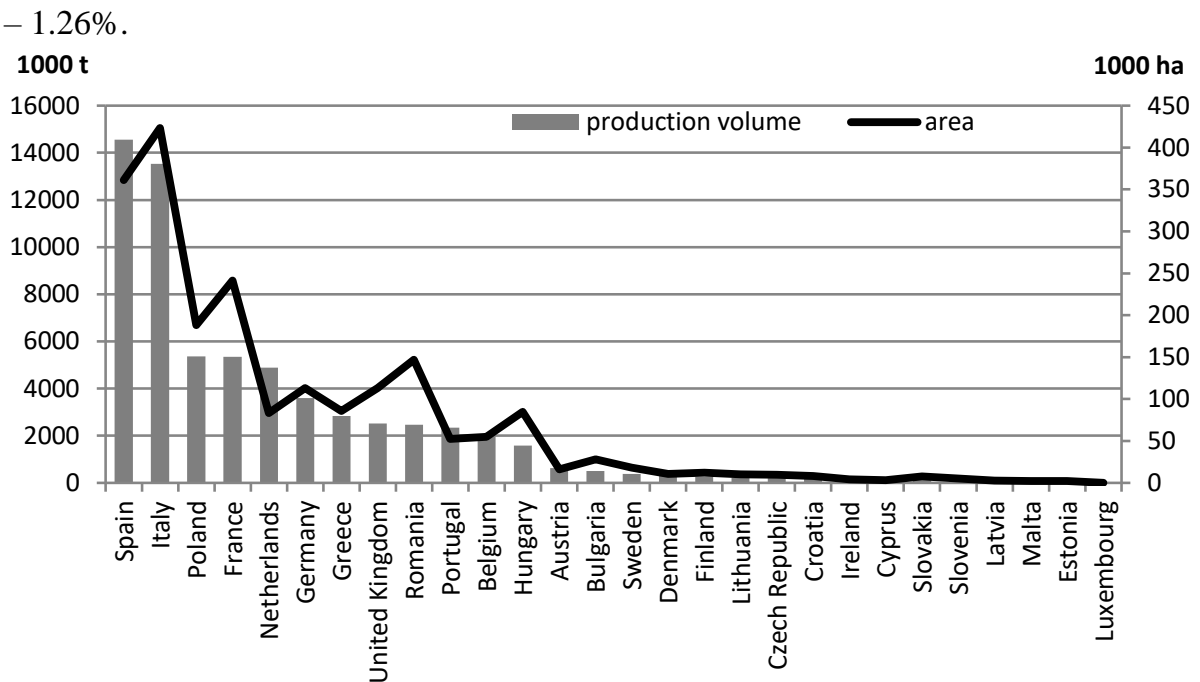

Fig. 1. Area (ha) and production volume (t) of vegetables in UE-28 average in the years 2014-2016, based on [4].

Eurostat data show that the area of cultivation has been growing since 2013. In 2014 it amounted to 2069 thous. ha. In the absence of a complete set of data from recent years, authors based on Eurostat data have estimated average annual crop area and 
vegetable production in EU-28 for 2014-2016 (fig. 1). The countries were rank in descending order according to a size of vegetable production. As can be seen in the graph serialization by the surface would give a different order.

It was estimated that in Italy vegetable crops area was the largest in EU-28 (423 thous. ha, ie 20.5\%). Crops in the next Spain and France together occupy 29.2\% of the EU area of these crops. Poland and Romania also had significant European vegetable growing areas. They accounted for $9.1 \%$ and $7.1 \%$, respectively. The relatively small area of these crops occurred in Germany and Great Britain, which are characterized by a large population. In each of these countries vegetable crops only accounted for $5.5 \%$ of the EU area. The total share of these crops acreage in these seven countries amounted to $76.7 \%$ of the EU.

Production of vegetables in the UE-28 in the years 2014-2016 was on average 64.3 mln tonnes a year and was conducted by about 920 thous. holdings in the area of over $2 \mathrm{mln}$ ha [4]. The largest vegetable producers in the EU were Spain and Italy (fig. 1). In total they produced $43.7 \%$ of all EU vegetables. Major growers of these crops were also Poland, France and the Netherlands. The level of vegetable production in Poland and France was similar $(5.3 \mathrm{mln}$ tonnes). A little less were produced in the Netherlands ( $4.9 \mathrm{mln}$ tonnes). Relatively few vegetables were produced in Germany, which has the highest population in the European Union.

\section{Structure of production and the main producers of vegetables in the $\mathbf{E U}$}

Vegetables are generally divided into qualitative and volumetric. The Eurostat data on vegetables describes 40 species of them divided into 6 groups [5]:

- brassicas (mainly cauliflower and broccoli, Brussels sprouts and cabbages),

- leafy and stalked vegetables (mainly lettuces, leeks and spinach),

- vegetables cultivated for fruit (mainly tomatoes, peppers and melons),

- root, tuber and bulb vegetables (mainly onions and carrots),

- fresh pulses (peas and beans),

- other fresh vegetables (for example caper, okra etc.)

Half the amount of vegetables produced in the EU-28 belongs to the group vegetables cultivated for fruit including melons (fig. 2). The volume of vegetable production in this group in 2016 amounted to 32274 thous. tonnes. Most of them are tomatoes. They represent $57.5 \%$ of vegetables in their group and $28.8 \%$ of total vegetables. An important place in this group occupies pepper, whose production in 2016 amounted to 2,519 thous. tonnes (almost 8\%).

Another group of vegetables in terms of production volume are root, tuber and bulb vegetables. In 2016 there were produced 14,187 thous. tonnes, ie over $22 \%$ of total EU-28 vegetable production. Most important in this group are onions (46.5\%) and carrots $(39.4 \%)$.

By volume of production, the third group of vegetables grown in EU-28 is leafy and stalked vegetables (14\% of all produced vegetables). In this group the most are 
produced lettuces. In 2016 it was 2,283 thous. tonnes, ie $25.1 \%$ of production in this group.

The fourth relatively small group is brassicas (10\% of all vegetables). In this group the most important role is played by cabbages, which was produced in the amount of 3,713 thous. tonnes, ie $60.2 \%$ of production in this group.

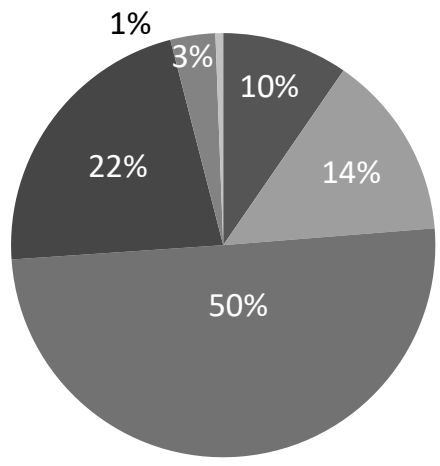

Brassicas

- Leafy and stalked vegetables

Vegetables cultivated for fruit (including melons)

Root, tuber and bulb

vegetables

Fresh pulses

Other fresh vegetables

Fig. 2. Structure of production of vegetables in UE in 2016, based on [4].

The number of vegetables included in the last two groups represents about $4 \%$ of all vegetables produced in the EU-28. Further analysis is focused on the four largest groups mentioned above. There were selected in each group vegetables produced in the biggest amount and then their area structure was analysed. In tab. 1 lists 10 countries which are the largest producers of a given vegetable. Next to the symbol of the country is its production share. The selected 6 species of vegetables are in turn according to the volume of production: tomatoes, onions, carrots, cabbage, peppers and lettuce.

Tomatoes are a vegetable, which are produced in the EU-28 in the largest amount $(18,545$ thous. tonnes in 2016). Their most important producers are Italy and Spain, which in 2016 collected together $63.7 \%$ of total tomatoes production in the Community. In turn, the 10 states listed in the tab. 1 first column produced $97.0 \%$ of this vegetable. In the case of tomatoes it can be observed the concentration of production in southern Europe. There is a climate conducive to the cultivation of these thermophilic crops.

In terms of production volume, the second vegetable in the EU-28 is onion $(6,576$ thous. tonnes). Spain apart from tomatoes is also an important producer of onions. It ranks the second after the Netherlands. Both countries together provide to the market $43.4 \%$ of the total onion production in the Community. In turn, the 10 largest manufacturers are responsible for $91.1 \%$ of this production.

The third very popular vegetable in Europe is carrot, which in 2016 was produced in the amount of 5,589 thous. tonnes. Almost $15 \%$ of this production took place in Poland. Great Britain, Germany, Holland and France each deliver to the market over $10 \%$ of total European production of carrots. The top 10 carrot producers account for $88.0 \%$ of this production. Carrot production is the domain of the countries located in warm temperate climate. 
Table 1. The biggest producers of selected vegetables in 2016 and their share in volume of production (\%), based on [4].

\begin{tabular}{c|r|r|r|r|r}
\hline Tomatoes & $\%$ & Onions & $\%$ & Carrots & $\%$ \\
\hline IT & 35.5 & NL & 22.0 & PL & 14.7 \\
ES & 28.2 & ES & 21.4 & UK & 12.9 \\
PT & 9.1 & PL & 9.9 & DE & 11.5 \\
GR & 5.5 & DE & 9.4 & NL & 10.7 \\
NL & 4.8 & FR & 7.0 & FR & 10.4 \\
PL & 4.7 & IT & 6.9 & IT & 9.5 \\
FR & 4.4 & UK & 5.9 & ES & 7.2 \\
RO & 2.3 & GR & 3.3 & BE & 6.9 \\
BE & 1.4 & RO & 2.9 & DK & 2.1 \\
HU & 1.1 & AT & 2.5 & RO & 2.0 \\
& & & & & $\%$ \\
\hline Cabbages & $\%$ & Peppers & $\%$ & Lettuces & $\%$ \\
\hline & & & & & \\
PL & 27.4 & ES & 46.7 & ES & 40.7 \\
RO & 16.6 & NL & 14.5 & IT & 14.1 \\
DE & 15.8 & IT & 6.9 & FR & 10.0 \\
UK & 6.2 & PL & 6.3 & DE & 9.1 \\
NL & 4.9 & GR & 6.0 & NL & 5.2 \\
ES & 4.4 & RO & 4.8 & UK & 4.7 \\
GR & 3.0 & HU & 4.7 & GR & 2.6 \\
PT & 2.9 & BG & 2.9 & BE & 2.3 \\
IT & 2.1 & FR & 1.7 & PT & 2.3 \\
BG & 2.0 & PT & 1.4 & AT & 1.9 \\
\hline
\end{tabular}

Cabbage also plays an important role among vegetables produced in Europe. In 2016, there were produced 3,713 thous. tonnes of this vegetable. Poland is the leader in cabbage production (27.4\%). The major producers are also Romania (16.6\%) and Germany (15.8\%). Cabbages are considered as a volumetric vegetable and its increased production in these countries results primarily from culinary traditions.

Another popular vegetable produced in Europe is peppers. In 2016 its collection was estimated at 2,519 thous. tonnes. The largest share of peppers production has Spain $(46.7 \%)$. The Netherlands ranked second (14.5\%). Ten of the largest producers of peppers in Europe corresponded in total for $95.9 \%$ of its production. The statistics of small European countries, i.e. Estonia, Luxembourg, Lithuania, Latvia, Malta did not demonstrated the production of peppers at all.

The last of the discussed vegetables that are grown in EU-28 in large quantities were lettuce (2,283 thous. tonnes in 2016). The leading producer of this vegetable is Spain. Its share in the EU production of this vegetable amounts to as much as $40.7 \%$. Another Italy and France produced together $24.1 \%$ of whole union production. The top ten producers account for a total of $92.9 \%$ of European salads. 


\section{International trade of vegetables inside and outside the EU}

Vegetables produced in the EU-28 are predominantly consumed in the Community. The average annual export volume of vegetables from EU countries in the years 20142016 was $27.5 \mathrm{mln}$ tonnes. Of this, $83.0 \%$ of vegetables went to the countries of the Community. On the other hand, 28.0 million tonnes were delivered to EU countries during the same period and $86.7 \%$ were from EU origin. The Community support local producers and protect their own market from vegetables originating mainly from China. Unfortunately, the EU is not self-sufficient.

In terms of value, the EU deficit in international vegetable trade was $2168 \mathrm{mln}$ EUR a year in the period 2014-2016. This accounted for 9.1\% of all vegetable imports to the EU. Of course, the Community countries are diverse in terms of export opportunities and import needs.

The EU vegetable market is another example of a market with concentration issues concerning the national point of view. To demonstrate this problem we performed a cluster analysis to identify countries that are the market makers i.e. important outliers by four main value variables: average internal import and export, average external import and export value over the surveyed period.

On the Fig. 3 there can be distinguished three clusters of countries as an optimal solution. The first one is the biggest one. It consists of $25 \mathrm{EU}$ countries. These countries, unlike Germany, Spain and the Netherlands, showed relatively little activity in the vegetable international trade over the period 2014-2016. The average value of intra-EU imports in this group did not exceed $490 \mathrm{mln}$ EUR, and exports $300 \mathrm{mln}$ EUR. In this group of countries, the United Kingdom is the country that is the largest net importer. The trade balance of UK with EU partners amounted to an average of $2562 \mathrm{mln}$ EUR per year in the analyzed tree year period.

A cluster of Spain and Netherlands is the last to join the rest. These two countries represent more than $55 \%$ of internal export performance and slightly over $50 \%$ in external vegetable export performance of the EU. Spain has the highest positive balance of vegetable sales in the EU market. Its value was 4603 mln EUR (Tab. 2) and the volume reached $4336 \mathrm{mln}$ tonnes of vegetables delivered on average per year to other EU countries. Spain has an extensive vegetable base and an average of 38.4\% of its production was exported to the markets of other European countries.

The second largest vegetable net exporter in Europe is the Netherlands. This country exports vegetables in quantities corresponding to $93.3 \%$ of its own production. In fact, a major part of it is connected with so-called "Rotterdam effect". This is related to the re-export of goods which are being transhipped at the Europe's leading seaport and register there, but are not destined for the Dutch market. Nevertheless, the balance of trade in vegetables is positive in the Netherlands and in the years 2014-2016 reached 3508 mln EUR.

The Germany was the last but one to be merged. It is due to an exceptionally high level of intra EU import which is $26 \%$ of total internal import. Germany is the largest net importer of vegetable in EU (Tab. 2). This is mainly due to the consumption needs of the vast population of this country. 


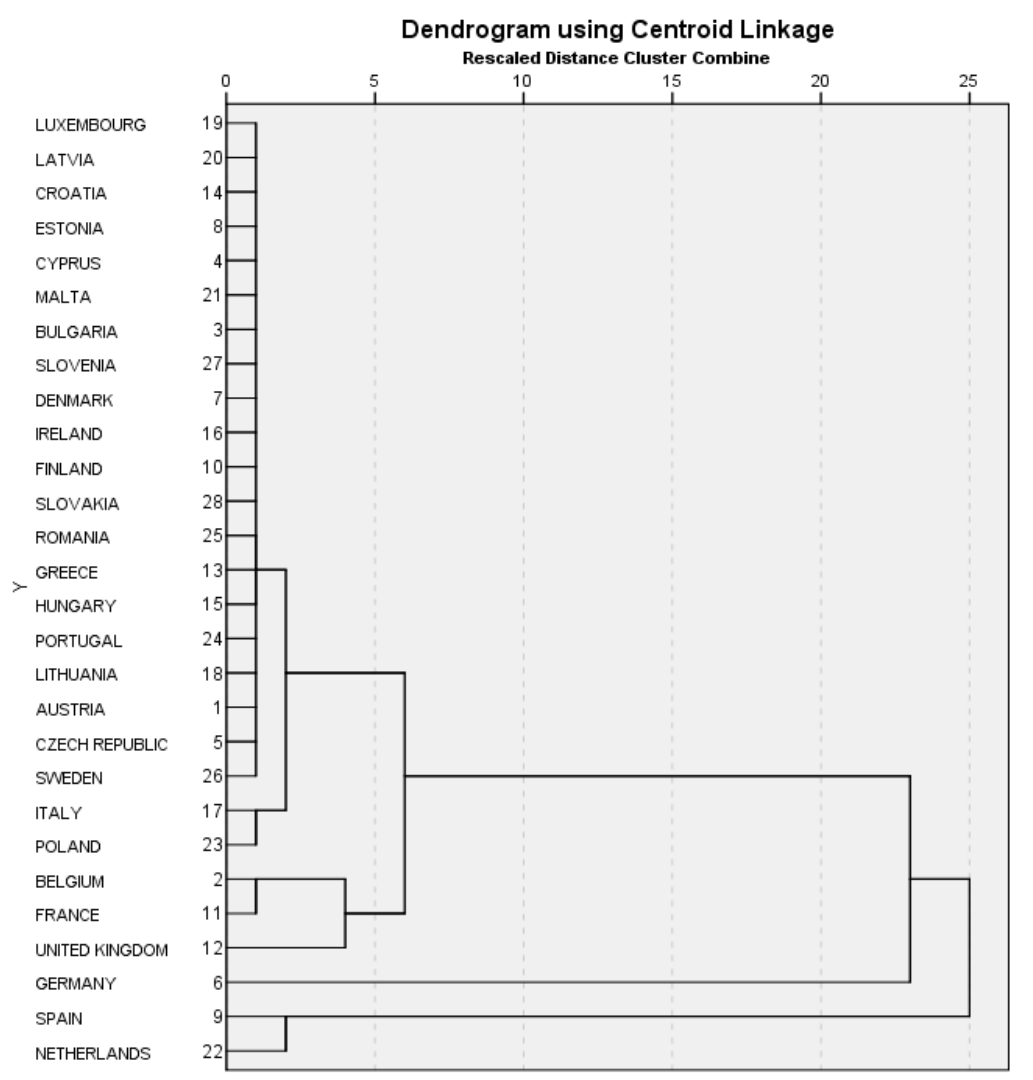

Fig. 3. Outliers identification based on average international trade values during 2014-2016, calculation based on [4].

Table 2. Result of the most important EU countries (outliers) in international trade in mln EUR, calculation based on [4].

\begin{tabular}{lrrrr}
\hline Country & EU import & EU export & nonEU import & nonEU export \\
\hline Germany & 5105.7 & 877.5 & 379.1 & 120.2 \\
Spain & 557.2 & 5159.7 & 487.7 & 366.5 \\
Netherlands & 1651.8 & 5160.1 & 561.1 & 1118.6 \\
\hline
\end{tabular}

To answer the question of the relative importance of internal and external international trade for each country a market size bias was treated by ipsative standardization. The agglomerative schedule suggested that the most suitable number of clusters is six clusters. However, as the dendrogram (Fig. 4) shows, see below, the optimal number of clusters is five.

After the centroid examination we found significant and explainable similarities of the second and the fourth cluster. Therefore, in Tab. 3 presents the division of EU states into 
5 groups. The results of relative importance bring more detailed insight on countries' position in the vegetable international trade, see tab. 3 .

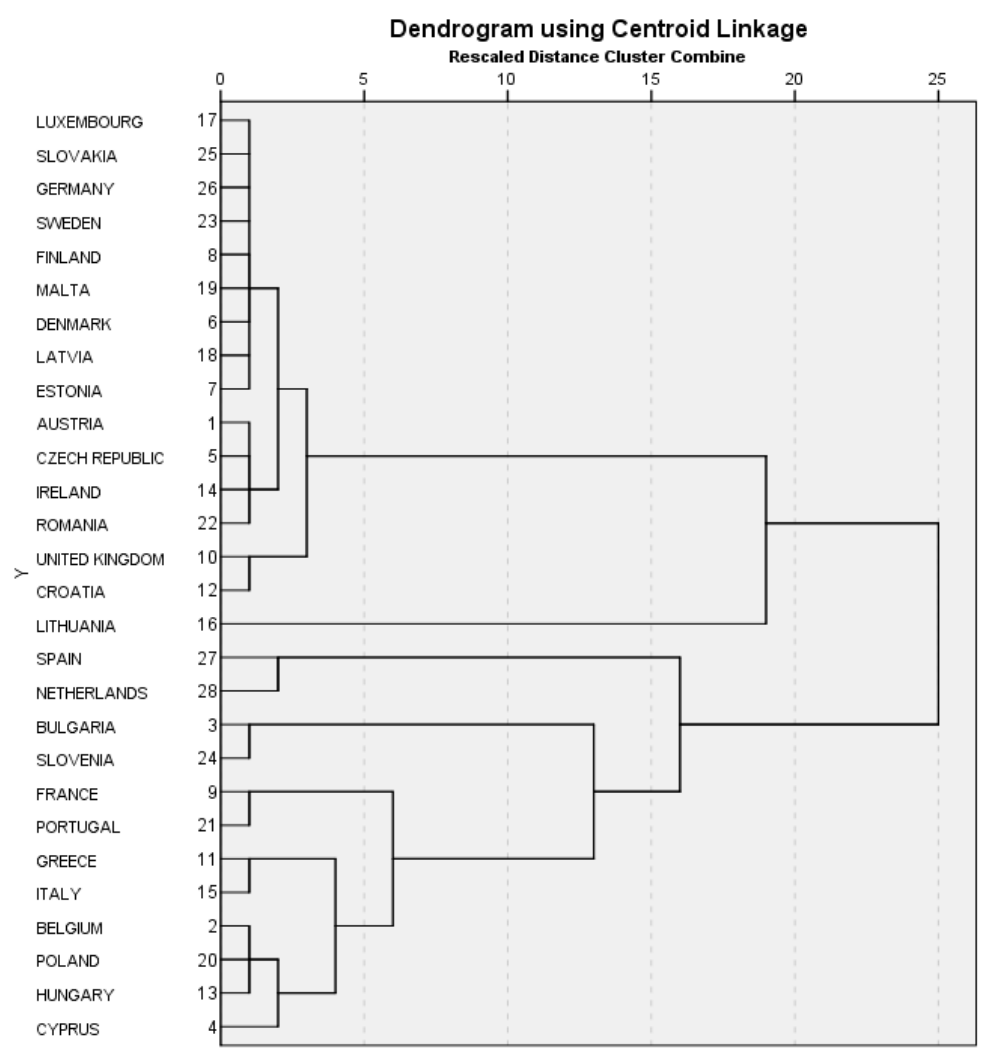

Fig. 4. Classification of countries by relative importance of intra-EU and extra-EU trade, calculation based on [4].

Table 3. Z-scores for classification of relative importance of international trade for UE countries, calculation based on [4].

\begin{tabular}{cccccc}
\hline $\begin{array}{c}\text { Cluster } \\
\text { no }\end{array}$ & Country symbol & $\begin{array}{c}\text { EU } \\
\text { import }\end{array}$ & $\begin{array}{c}\text { EU } \\
\text { export }\end{array}$ & $\begin{array}{c}\text { nonEU } \\
\text { import }\end{array}$ & $\begin{array}{c}\text { nonEU } \\
\text { export }\end{array}$ \\
\hline \multicolumn{7}{c}{$\begin{array}{c}\text { LU, SL, DE SE, } \\
\text { FI, MT, DK, LV, } \\
\text { EE, AT, CZ, IE, } \\
\text { RO, GB, HR }\end{array}$} & 1,69 & $-0,34$ & $-0,61$ & $-0,74$ \\
& GR, IT, BE, PL, & 0,92 & 0,98 & $-0,78$ & $-1,12$ \\
\hline 2 & HU, CY, FR, PT & 0,91 & 0,53 & 0,24 & $-1,68$ \\
\hline 3 & BG, SI & $0,0,65$ & $-1,26$ & 0,67 \\
\hline 4 & FR, PT & 1,24 & $-0,69$ & $-0,59$ \\
\hline 5 & ES, NL & $-0,40$ & 1,71 & $-0,72$ & \\
\hline
\end{tabular}


Based on clusters assessment concerning relative importance of international trade each country of EU can be classified to one of following group - counties in which:

1. intra-EU import importance is very high - not self-sufficient countries with high intra-EU deficit,

2. intra-EU import and intra-EU export importance is high - not selfsufficient countries in commodity structure only which are relying on intra-EU trade, value is mostly balanced,

3. intra-EU import importance is very high and only average concerning intra-EU export - not self-sufficient countries in commodity structure only which are relying on both intra and extra-EU import,

4. Very high importance has intra-EU import and above high average importance has extra-EU export - not self-sufficient countries relying on intra-EU import but partially balancing their net position by extra-EU trade,

5. Intra-EU export is very high important - surplus net position country.

\section{Conclusion}

Vegetables are becoming increasingly important part of the daily diet of Europeans. Growing demand for vegetables and growing their production. Vegetable farming occupies a relatively small area of agricultural land in the EU. For a few years there has been a slight increase in the area of vegetable cultivation. The current EU legislation favors enlarging production and linking producers in the group. The cultivation of vegetables has been covered by the instruments of the common agricultural policy, which is supposed to contribute to the development of production. Most of the vegetables produced in the EU is consumed in its territory. Unfortunately, the Community is not self-sufficient.

EU vegetable production is diversified and concentrated regionally. In southern countries, i.e. Spain and Italy, nearly $44 \%$ of EU production is concentrated. In Spain, productivity is higher than in Italy. Spain is also the largest net exporter of vegetables on the EU territory. It supplies $27.6 \%$ of all EU vegetable exports to the EU. Spain is an unrivaled vegetable producer and exporter in the EU. It possesses huge resources of land, has a very favorable climate and ever increasing production capacity. It has the highest share in the EU in the production of peppers (46.7\%) and lettuce (40.7). It ranks second in terms of tomato production (28.2\%) and onion $(21.4 \%)$.

From the new Member States, Poland is an important vegetable producer in the EU. It has a large production area and specializes mainly in the production of cabbage and carrots belonging to the volumetric vegetables. However, Poland does not play a big role in the international trade of vegetables. An important position as a European manufacturer of vegetables occupies the Netherlands. The vegetable production in this country is very efficient and modern. It is the EU's leading producer of onions.

Cluster analysis shown that the vegetable market is another proof of half-way closed economic center. EU economic center is relying heavily on internal market making it far less opened compared to e.g. center in the Asia or the North America. 
There is one large group of mostly smaller countries that are not self-sufficient concerning vegetable production but they are saturated from internal EU sources and therefore they manifest high EU internal trade deficit. The second group contains regions that are balanced regarding the EU internal trade. Only France and Portugal show high importance of the external EU export regarding their trade structure. High activity of the Netherlands in the international exchange of vegetables is caused by so-called Rotterdam effect and also Spain is very strong surplus region in the EU.

Acknowledgements. This paper was written with the financial support of Specific Research Project 3/2017 at Faculty of Informatics and Management of the University of Hradec Kralove. We thank Martin Kral for help with a literature search.

\section{References}

1. Council of the European Union: Council Regulation (EC) No 2200/96 of 28 October 1996 on the common organization of the market in fruit and vegetables. Official Journal of the European Communities. L 297/1

2. Council of the European Union: Council Regulation (EC) No 2201/96 of 28 October 1996 on the common organization of the market in processed fruit and vegetables products. Official Journal of the European Communities. L 297/29.

3. Council of the European Union: Council Regulation (EC) No 1234/2007 of 22 October 2007 establishing a common organisation of agricultural markets and on specific provisions for certain agricultural products (Single CMO Regulation). Official Journal of the European Union. L 299/1

4. Eurostat database, http://ec.europa.eu/eurostat/data/database, last accessed 2017/10/20.

5. Eurostat: Eurostat Handbook for Annual Crop Statistics (Regulation EC No 543/2009, Commission Delegated Regulation EU 2015/1557 and ESS agreement for Annual Crop Statistics). http://ec.europa.eu/eurostat/cache/metadata/Annexes/apro_acs_esms_an1.pdf, last accessed 2017/10/30.

6. FAOSTAT, http://www.fao.org/faostat/en/\#data, last accessed 2017/10/30.

7. Filipiak, T.: Uwarunkowania prawno-organizacyjne sektora owoców i warzyw w Polsce. Roczniki Naukowe Stowarzyszenia Ekonomistów Rolnictwa i Agrobiznesu, 15(3), 63-69 (2013).

8. Food and agricultural organization: Fruit and Vegetables for Health, Report of a Join FAO/WHO Workshop, 1-3 September 2004, Kobe, Japan, http://apps.who.int/iris/ bitstream/10665/43143/1/9241592818_eng.pdf, last accessed 2017/10/15.

9. Hair, J. F. Jr., Black, W. C., Babin B. J., Anderson, R. E.: Multivariate Data Analysis. Pearson, New Jersey (2006).

10. Hebák, T. et al.: Vícerozměrné statistické metody vol. 1. Informatorium, Prague (2004).

11. Hebák, T. et al.: Vícerozměrné statistické metody vol. 3. Informatorium, Prague (2005).

12. Kowalska A.: Polski handel zagraniczny produktami branży chemicznej. Przemysł Chemiczny 94(5). 637-641 (2015) DOI:10.15199/62.2015.5.1

13. Mooi, E., Sarstedt, M.: A Concise Guide to Market Research: The Process, Data, and Methods Using IBM SPSS Statistics. Springer-Verlag, Berlin Heidelberg (2014).

14. Řezanková, H. et al.: Shluková analýza dat. 2nd edn. Professional publishing, Prague (2009). 
15. Welbaum G. E.: Vegetable Production and Practices, CAB International, Wallingforth, Oxfordshire (2015).

16. Yarnold, P., Soltysik, C.R.: Ipsative Standardization is Essential in the Analysis of Serial Data. Optimal Data Analysis. 2(2), 94-97 (2013). 